\title{
A Procedure for NEPA Assessment of Selenium Hazards Associated With Mining
}

\author{
A. Dennis Lemly
}

Received: 8 July 2005 / Accepted: 14 November 2005 / Published online: 18 January 2007

(C) Springer Science + Business Media B.V. 2007

\begin{abstract}
This paper gives step-by-step instructions for assessing aquatic selenium hazards associated with mining. The procedure was developed to provide the U.S. Forest Service with a proactive capability for determining the risk of selenium pollution when it reviews mine permit applications in accordance with the National Environmental Policy Act (NEPA). The procedural framework is constructed in a decision-tree format in order to guide users through the various steps, provide a logical sequence for completing individual tasks, and identify key decision points. There are five major components designed to gather information on operational parameters of the proposed mine as well as key aspects of the physical, chemical, and biological environment surrounding it - geological assessment, mine operation assessment, hydrological assessment, biological assessment, and hazard assessment. Validation tests conducted at three mines where selenium pollution has occurred confirmed that the procedure will accurately predict ecological risks. In each case, it correctly identified and quantified selenium hazard, and indicated the steps needed to reduce this hazard to an acceptable level. By utilizing the procedure, NEPA workers can be confident in their ability to understand the risk of aquatic selenium pollution and take appro-
\end{abstract}

A. D. Lemly $(\bowtie)$

United States Forest Service Southern Research Station, Fisheries Research Unit, 1650 Ramble Road,

Blacksburg, VA 24060, USA

e-mail: dlemly@fs.fed.us priate action. Although the procedure was developed for the Forest Service it should also be useful to other federal land management agencies that conduct NEPA assessments, as well as regulatory agencies responsible for issuing coal mining permits under the authority of the Surface Mining Control and Reclamation Act (SMCRA) and associated Section 401 water quality certification under the Clean Water Act. Mining companies will also benefit from the application of this procedure because priority selenium sources can be identified in relation to specific mine operating parameters. The procedure will reveal the point(s) at which there is a need to modify operating conditions to meet environmental quality goals. By recognizing concerns early in the NEPA process, it may be possible for a mining company to match operational parameters with environmental requirements, thereby increasing the likelihood that the permit application will be approved.

Keywords Aquatic selenium pollution - Ecological risk assessment $\cdot$ Environmental impact statement . Mining $\cdot$ National forests $\cdot$ NEPA $\cdot$ SMCRA $\cdot$ TMDLs

\section{Introduction}

Selenium is a naturally occurring chemical element that can be concentrated and released in the waste materials from industry, agriculture, mining, and petrochemical operations. Once in the aquatic environment, it can bioaccumulate and reach levels that are toxic to fish and 
wildlife (Fig. 1). Impacts may be rapid and severe, with teratogenic deformities and reproductive failure eliminating entire communities of fish and causing total reproductive failure in local populations of aquatic birds (Lemly 1985; Ohlendorf 1989). Few environmental contaminants have the potential to affect aquatic resources on such a broad scale, and even fewer exhibit the complex aquatic cycling pathways and range of toxic effects that are characteristic of selenium (Lemly 2002a; Lemly and Smith 1987; Ohlendorf et al. 1988). In recent years there has been an escalation in selenium pollution episodes on a global scale, which has caused land management issues for the Forest Service and many other natural resource agencies (Lemly 2004). Consequently, there is a growing need for assessment methods and technical expertise to evaluate selenium problems.

Mining activities on national forests in the U.S. are producing selenium-laden wastes, causing substantial ecological damage, and creating important legal liabilities. Noteworthy episodes of selenium pollution have resulted from phosphate mining on Caribou National Forest, Idaho, where domestic livestock as well as fish and wildlife were poisoned (Fig. 2; CCS 1999; Hamilton and Buhl 2003a, b, 2004; Hamilton et al. 2002; Lemly 1999; Piper et al. 2000; Skorupa et al. 2002; Steele 2003), and gold mining on BeaverheadDeerlodge National Forest, Montana, where a recreational cutthroat trout fishery was contaminated (La Marr 2002, 2003). This pollution is happening because the Forest Service lacks methods to identify and evaluate ecological risks from selenium in geologic deposits when it conducts pre-mine investigations required for NEPA (National Environmental Policy Act). Under NEPA, federal land management agencies must assess potential ecological impacts of their planned activities in a formal Environmental Impact Statement (EIS), or a less rigorous Environmental Assessment (EA), and take steps to ensure that unacceptable impacts are prevented. With regard to mining, issuance of a permit by the Forest Service should take place only if the EIS or EA clearly shows that degradation of water quality and contamination of aquatic habitats will not occur. Ideally, the decision would be based on a comprehensive, site-specific evaluation of the proposed mine with the aid of corroborating information from existing mines. However, lack of selenium assessment methods prevents the Forest Service from conducting a thorough and complete EIS or EA, and decisions are made without knowing if selenium could become a problem (e.g., USDA-FS 1988). Thus, mining permits are issued without understanding the potential for selenium pollution. These oversights result in violation of NEPA as well as other federal acts that pertain to water quality and wildlife health; for example, the Clean Water Act, Endangered Species Act, and Migratory Bird Treaty Act. The Forest Service is liable for environmental damage that occurs as a result of these violations, and the Agency and/or specific individuals can be held accountable through legal actions. Indeed, selenium-related lawsuits and environmental appeals
Fig. 1 Pathways for selenium movement from mine wastes, bioaccumulation in food chains, and dietary exposure of fish and wildlife populations in aquatic habitats
MAJOR ECOLOGICAL RISKS ON NATIONAL FORESTS

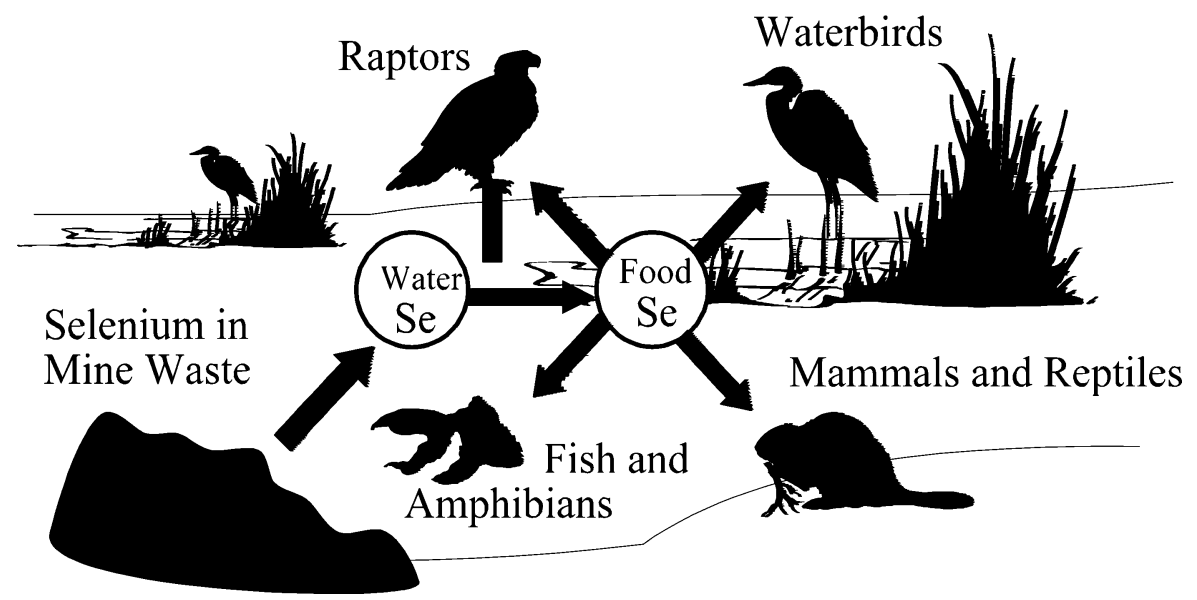




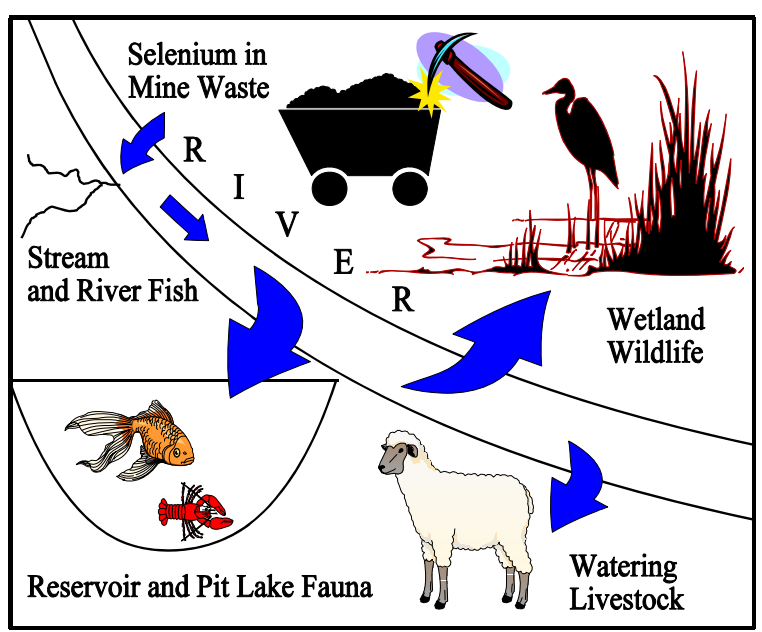

Fig. 2 Selenium released from phosphate mining on Caribou National Forest, Idaho, contaminated aquatic habitats and associated animals in the Blackfoot River basin. This pollution resulted in the death of seven horses and over 500 sheep, caused embryonic deformities in waterbirds and salamander die-offs, and contaminated fish to the extent that consumption warnings were posted along streams by the Idaho Department of Health and Welfare

have been brought against the Forest Service repeatedly in the past decade (e.g., GYC 1999; IFPR 2003; USDC 2002).

Pollution episodes such as those mentioned above have significant negative effects on the Forest Service. They damage the Agency's credibility as a conservation leader and force it to divert personnel and money needed for other forest management activities into a hectic scramble to gather information and respond to the public, usually in the midst of lawsuits. There are thousands of hectares of coal and mineral leases either approved or under review by the Forest Service for mining in the Sierra Nevada, Cascade, Rocky, and Appalachian Mountains. Much of this mining has the potential to cause selenium contamination of aquatic habitats if it does not receive proper NEPA assessment. Until now the Forest Service has only been able to operate in a reactionary mode, that is, responding after contamination and ecological damage has occurred. Clearly, there is a need to develop and apply a new component in the NEPA process that will provide a proactive capability to address the risk of selenium pollution on national forests. This need is not limited to the Forest Service. Other federal land management agencies that conduct NEPA assessments would benefit from such a capability as well as regulatory agencies responsible for issuing coal mining permits under the authority of the Surface Mining Control and Reclamation Act (SMCRA), and associated Section 401 water quality certification under the Clean Water Act. This paper provides that proactive capability in the form of an operational procedure for pre-mine assessment of aquatic selenium hazards.

\section{Procedure}

The procedural framework is constructed in a decision-tree format in order to guide users through the various steps, provide a logical sequence for completing individual tasks, and identify key decision points (Fig. 3). There are five major components designed to gather information on operational parameters of the proposed mine as well as key aspects of the physical, chemical, and biological environment surrounding it. Each component requires a different type of expertise to complete and it is not expected that Forest Service NEPA workers will necessarily be able to provide the needed skills. In fact, they should not hesitate to enlist the counsel and guidance of experts in selenium ecotoxicology and biogeochemistry whenever questions arise or they wish to have a technical review of the selenium data, model projections, and their proposed permit decision. However, they should be well capable of overseeing the process and following the procedural steps of each component to make sure that all needed information is gathered, examining results, and developing recommendations for action on the permit. The mining company applying for the permit should be responsible for securing necessary manpower and technical expertise either by providing their own personnel or retaining contractors approved by the NEPA worker (for example, contractors for sampling and ecological characterization, laboratories for analytical chemistry, selenium experts for technical reviews, etc.) as well as bearing all associated costs, whether or not the permit is issued (for example, pre-mine core drilling and selenium analysis, biological and hydrological assessment, compliance monitoring, etc.). Successful completion of the procedure will provide NEPA workers with a solid, science-based foundation for either taking action on permit applications directly or recommending actions which can be passed to higher level NEPA officers for final review if required. 
Fig. 3 Framework for identifying and interpreting selenium hazards associated with mining

\section{NEPA DECISION TREE FOR SELENIUM}

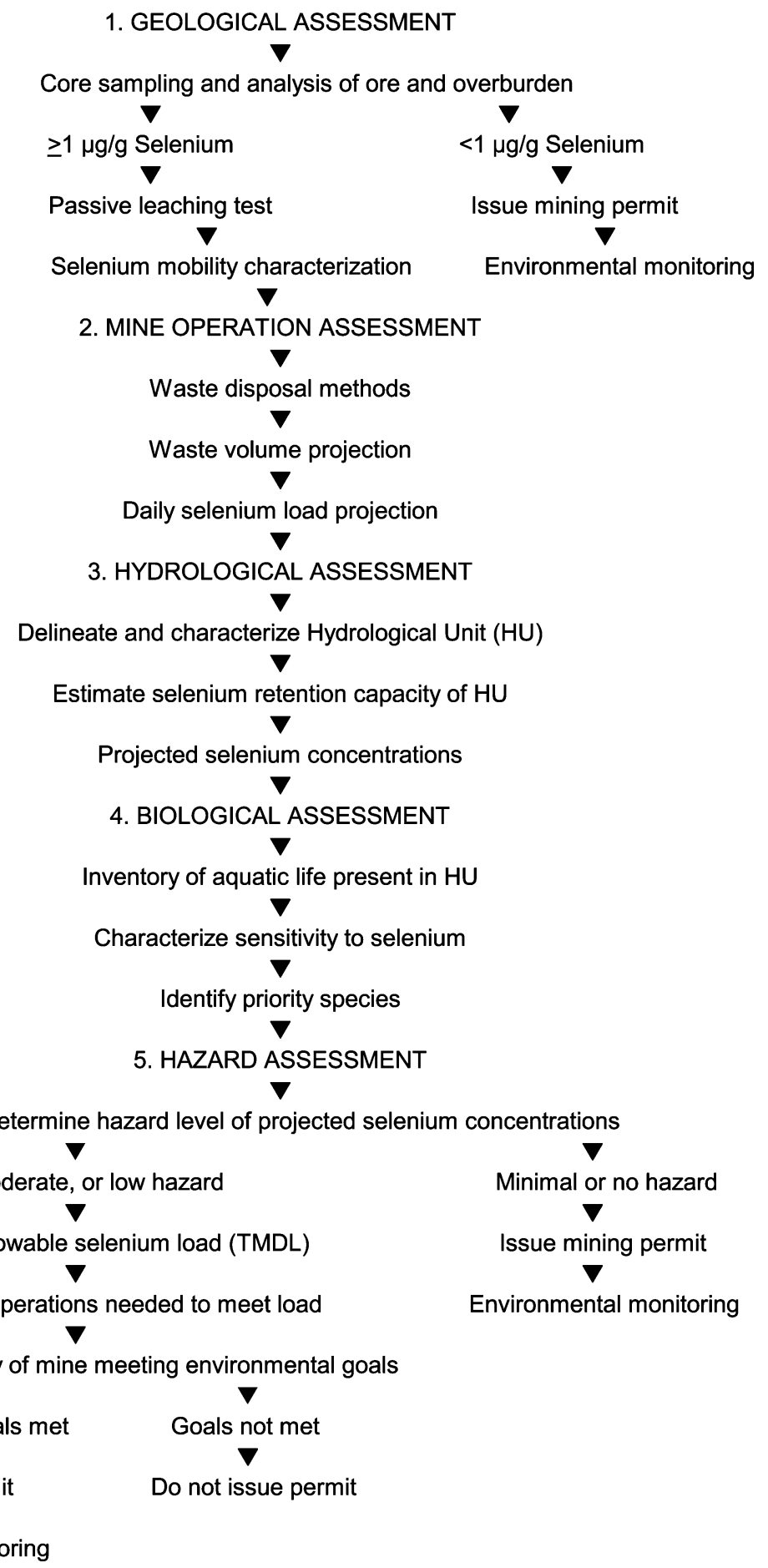




\subsection{Component 1 - geological assessment}

Geological assessment is the first step to understanding the environmental risk of selenium at prospective mines. It is essential to characterize the selenium present in the geologic strata that are to be disturbed because once these materials are exposed to air and precipitation they can leach substantial quantities of selenium (Davis and Boegly 1981; Heaton et al. 1982; Herring 2004), which begins the mobilization process and threat to aquatic life. Because selenium concentrations vary widely in the target matrix and waste rock at a mine site (Desborough et al. 1999; Heaton and Wagner 1983; Perkins and Foster 2004), a thorough representation of the intended geographic area and depth of disturbance by mining must be made. This entails making a minimum of one core drilling per 5 acres, extending into the target matrix (coal or mineral ore) that is to be extracted. The designation of a 5 acre spacing for cores is based on the need to have an adequate number of samples (10 or more) for the analysis if the proposed area to be mined is relatively small ( $<100$ acres), while at the same time not requiring excessive drilling if the site is large (>500 acres). Two samples (about $450 \mathrm{~g}$, or $1 \mathrm{lb}$, each) are taken from each core; one consisting of overburden material and one of the target matrix itself. For locations where the target matrix is in horizontal seams this should be a fairly straightforward process. At locations where the target matrix is present in vertical seams that extend to (or very near) the surface and the seams are separated by interburden, two cores would need to be taken; one in the interburden and one in the target matrix. Overburden or interburden samples need to be taken from well below the surface organic layer of soil $(>1 \mathrm{~m})$ to prevent analysis of material that is non-typical, i.e., already weathered and leached resulting in a different mineral or trace element content. It is not necessary to take subsamples from several intervals within a core and composite them to make the $450 \mathrm{~g}$ sample, a single chunk or mass of material will suffice. The next step is to crush the coarse sample with a hammer to produce approximately pea-size or smaller material, mix it thoroughly, and divide it into two equal parts; one to be analyzed for selenium content and one set aside for subsequent leaching tests, if necessary. Each of these parts should be labeled with the collection date, material (target matrix or overburden) and location collected. Each sample should be analyzed for total selenium concentration, which can be done by a contract laboratory that is EPA-certified to analyze soils and solid waste for trace elements. If the maximum selenium content of the samples is less than $1 \mu \mathrm{g} \mathrm{Se} / \mathrm{g}$ (microgram selenium per gram or part per million) dry weight, then the amount of selenium leaching from ore and waste materials should pose minimal risk to aquatic life, that is, it should not bioaccumulate to the point that it becomes toxic (Desborough et al. 1999; Herring 2004; Lemly 1993a, 1994). Consequently, there is no need to conduct the subsequent steps in this protocol (mine operation assessment, hydrological assessment, biological assessment, hazard assessment). At this point the NEPA worker can recommend issuing the mining permit with the stipulation that aquatic habitats be monitored once mining begins to make sure that environmental quality goals are met and maintained (see Component 5-hazard assessment for monitoring guidance).

If the concentrations of selenium in the core samples are greater than or equal to $1 \mu \mathrm{g} \mathrm{Se} / \mathrm{g}$ dry weight, then it is necessary to proceed with leaching tests. The technique recommended here is a modification of the standard test method for shake extraction of solid waste with water (ASTM 2004), as adapted for use by the U.S. Geological Survey to evaluate selenium mobility in mined materials (Desborough et al. 1999; Heaton et al. 1982). The procedure was modified to more closely approximate typical environmental leaching conditions for selenium. For example, the ASTM method specifies shaking the sample but allows only $18 \mathrm{~h}$ for interaction with water; the modification does not require shaking but provides $48 \mathrm{~h}$ for leaching to occur. The key steps in this leaching test are given here as reference information for the NEPA worker. This test can be done by a contract laboratory that is EPAcertified to analyze water samples for selenium. For each sample to be leached, some is put into a glass container with deionized water $(\mathrm{pH} 5.0-6.0)$ in a ratio of 1 part sample to 20 parts water (use 10-20 g of sample and $200-400 \mathrm{~mL}$ of water). The container is left undisturbed for $48 \mathrm{~h}$, then the liquid is decanted and filtered $(0.45 \mu \mathrm{m}$ mesh), acidified to $\mathrm{pH}<2.0$ with reagent grade hydrochloric acid, and analyzed for selenium concentration using a standard EPA-approved method with a detection limit $<1 \mu \mathrm{g}$ selenium per-liter ( $\mu \mathrm{g} \mathrm{Se} / \mathrm{L}$ or part-per-billion; for example, atomic absorption spectrophotometry using a graphite furnace and hydride generation). The results 
of the leaching tests will generate a spatial profile of selenium mobility that is likely to occur from weathering of exposed materials at the mine site. The leachate selenium concentration data will be used to project daily selenium loading and also be applied in the hazard assessment phase of the procedure. This protocol specifies the use of fresh core material in the leaching tests in order to obtain results and make a geological assessment in a timely manner. However, it should be noted that using fresh core material that has not been aged or weathered for several months prior to leaching will yield a conservative estimate of the selenium mobility that may take place at actual waste rock piles in a mine setting (Desborough et al. 1999; Herring 2004).

\subsection{Component $2-$ mine operation assessment}

The disposal method(s) used for solid and liquid wastes at a mine greatly affect the potential amount of selenium released and thus the risk of ecological damage (Lemly 1994). It is important to know approximately how much excavated solid material will be exposed to weathering at any given time, as well as how much liquid will be produced, whether held in tailings ponds or directly discharged into receiving waters. The engineering design should be examined closely to provide waste volume estimates that are as accurate as possible. Once these numbers are obtained, some calculations will provide estimates of daily selenium loading, that is, how much selenium is likely to be released to the surrounding environment. For liquid waste the process is straightforward. Simply multiply the maximum concentration of selenium in the leachate tests ( $\mu \mathrm{g} \mathrm{Se/L}$ ) by the average daily volume of wastewater (liters, L) that is projected to occur once the mine is fully operating, and convert to grams $\left(1 \mu \mathrm{g} \mathrm{Se} / \mathrm{L} \times 10^{6} \mathrm{~L}=1 \mathrm{~g} \mathrm{Se}\right)$. For solid waste, five steps are necessary. First, using local climate records (available at websites such as http://www. ggweather.com/normals or http://www.ncdc.noaa.gov/ oa/climate) determine the average annual precipitation, in centimeters, for the mine site. This is the gross amount of moisture available for potential leaching of selenium from exposed solid material (target ore, overburden and mine processing waste). Second, reduce this number by $50 \%$ to allow for evaporation because not all of the precipitation will percolate downward through the waste rock and produce leach- ate. The resultant value is the net moisture. Third, multiply the net moisture times the surface area, in hectares ( 1 acre $=0.4047$ ha), of exposed solid materials to estimate the total annual leachate volume (depth-area-volume conversion: $1 \mathrm{~cm} \times 1$ ha $=$ $100,000 \mathrm{~L})$. Fourth, divide the result by 365 to find the expected daily leachate discharge volume. Fifth, multiply the maximum concentration of selenium in the leachate tests by the daily volume of discharge to determine daily selenium load, in grams, from solid waste (for example, $100 \mu \mathrm{g} \mathrm{Se} / \mathrm{L} \times 10^{6} \mathrm{~L}=100 \mathrm{~g} \mathrm{Se}$ ).

Finally, add the daily load number for liquid waste to the number for solid waste in order to find the expected maximum total daily selenium load generated by the mine. This number represents the maximum possible amount reaching surface waters since certain geochemical and hydrological factors may reduce the discharge; for example, variation in leachate concentrations or percolation of some liquid downward into the water table before it leaves the mine site. Nevertheless, it is necessary to use the highest values to estimate selenium loading because it is the maximum concentrations, rather than averages, that provide a majority of the fuel for selenium's "bioaccumulation engine" and subsequently cause ecological damage (Lemly 1998).

\subsection{Component 3-hydrological assessment}

The surface water hydrology of the basin surrounding the proposed mine must be carefully examined in order to identify all potential receiving waters for selenium discharges. Because of hydrological connections between the various aquatic habitats that may be present in a watershed basin, the toxic threat from selenium contamination is also connected. The hydrologically linked parts of a watershed that are down-gradient of the mine site, extending to the point at which outside water sources dominate the hydrology (for example, confluence of the watershed with a larger drainage basin) should be the area evaluated. This physical area constitutes a hydrological unit (HU). The protocol given in this paper aims to protect the weakest link in the $\mathrm{HU}$, that is, habitats where the risk of selenium accumulation and toxicity to aquatic life are greatest. In order for the assessment and resultant mine permitting decisions to be environmentally sound it is necessary to map and characterize the aquatic system of the HU. This can be done using previously available mapping 
information in combination with field reconnaissance to identify/verify hydrological connections and document some key ecological factors that contribute to selenium accumulation. Begin by identifying all aquatic habitats within the HU; wetlands (ephemeral vernal wetlands and permanent wetlands), marshes, bogs, streams, rivers, off-channel bays, lakes, reservoirs, and ponds (including existing or proposed mine pit lakes or waste storage ponds). Map their spatial and gradient/hydrological relationships, that is, know what flows where and into/out of what. Obtain information on prevailing sediment type (organic, inorganic, mixed) and volume replacement times or flushing rates for lakes, reservoirs and other impoundments, bays of main-stem rivers, and wetlands. Determine the predominant flow regime (slow, moderate, swift) and dominant sediment characteristics (depositional, erosional, particle size, organic, inorganic, mixed) of flowing-water habitats. Large rivers merit special attention in order to identify, describe, and map the variety of habitats that may be present; for example, off-channel bays, seepage or floodplain wetlands, etc. Characterize the general level of primary productivity for each aquatic habitat and, from this, determine trophic status (low productivity $=$ oligotrophic, moderate productivity $=$ mesotrophic, high productivity = eutrophic).

With this information in hand, the next step is to estimate the selenium retention capacity (RC) of the HU. This will determine the sensitivity of the HU to selenium and, thereby, serve as an indicator of how much selenium the system can safely assimilate. For the purposes of this NEPA procedure, $\mathrm{RC}$ is defined as the propensity of an aquatic system to accumulate and conserve selenium. Components of RC include bioaccumulation, detrital retention, physical and chemical sequestration, and recycling within the HU. The more that selenium is held within a HU - whether incorporated into biota, deposited in sediments, etc. - the higher the RC. It is necessary to know RC in order to develop an environmentally sound maximum acceptable daily selenium load for the HU (to be determined in Component 5-hazard assessment). The higher the RC, the lower the Total Maximum Daily Load (TMDL) has to be to prevent toxic threats to fish and wildlife (Lemly 2002b).

To a large extent, $\mathrm{RC}$ depends on the degree of selenium bioaccumulation and internal recycling in the HU, which is reflected in (1) primary productivity, (2) water flow regime, and (3) sediment type. From the HU characterization done thus far, information on these three factors will be available for each aquatic habitat. Use the matrix in Table 1 to assign each of these factors a separate RC rating: low, medium, or high. A rating should be done for each distinct habitat within the $\mathrm{HU}$, that is, each wetland, marsh, bog, stream, river, off-channel bay, lake, reservoir, pond, etc. An overall $\mathrm{RC}$ rating for each habitat is determined by combining the three factor ratings ( 1 for productivity, 1 for flow, 1 for sediment) as follows:

3 low ratings $=$ low $\mathrm{RC}$

2 low and 1 medium $=$ low $\mathrm{RC}$

2 low and 1 high $=$ medium $\mathrm{RC}$

2 medium and 1 low $=$ medium $\mathrm{RC}$
Table 1 Retention capacity (RC) ratings for selenium in aquatic systems based on habitat type and general biological/physical characteristics

\begin{tabular}{llll}
\hline & Habitat type & & \\
\cline { 2 - 4 } & $\begin{array}{l}\text { Stream, main-stem } \\
\text { river }\end{array}$ & $\begin{array}{l}\text { Lake, reservoir, off-channel } \\
\text { bay, impoundment }\end{array}$ & $\begin{array}{l}\text { Bog, marsh, } \\
\text { wetland }\end{array}$ \\
\hline $\begin{array}{l}\text { Primary productivity } \\
\text { High (eutrophic) }\end{array}$ & High & High & High \\
$\begin{array}{l}\text { Moderate (mesotrophic) } \\
\text { Low (oligotrophic) }\end{array}$ & Medium & Medium & Medium \\
Water flow & Low & Low & Low \\
Swift & Medium & Low & Low \\
Moderate & High & Medium & Medium \\
Slow & High & High \\
Sediment & Low & Low & Low \\
Inorganic & Medium & Medium & Medium \\
Mixed & High & High & High \\
Organic & & & \\
\hline
\end{tabular}


2 medium and 1 high $=$ medium $\mathrm{RC}$

3 medium ratings $=$ medium $\mathrm{RC}$

2 high and 1 low $=$ medium $\mathrm{RC}$

2 high and 1 medium $=$ high $\mathrm{RC}$

3 high ratings $=$ high $\mathrm{RC}$

The final RC rating for the HU should be set equal to the highest individual habitat rating. For example, if there are two habitats with low $\mathrm{RC}$ and one with medium, the final $\mathrm{RC}$ rating for the $\mathrm{HU}$ is medium.

The last step in this component of the procedure is to estimate the environmental concentrations of selenium that could result from the projected mine discharge. In order to do this, take the RC rating and apply it to the solid waste leachate numbers. If RC is low, then use $1 \%$ of the maximum leachate selenium concentration as the expected waterborne level. If RC is medium, use $5 \%$ of the leachate test concentration. If $\mathrm{RC}$ is high, use $10 \%$ of the leachate test concentration as the expected waterborne selenium level (these percentages were derived from field research at the mines used for case examples in this paper by using data for known conditions of $\mathrm{RC}$, leachate selenium, waterborne selenium, and tissue concentrations of selenium). Multiply the expected waterborne value by a bioaccumulation factor of 3,500 (Lemly 1985, 1996; Ogle et al. 1988; Ohlendorf 1989) to estimate the tissue concentrations that would result in selenium-sensitive species of fish and wildlife feeding in the HU once a watersediment-foodweb equilibrium in selenium transfer was reached $(1 \mu \mathrm{g} \mathrm{Se} / \mathrm{L}=0.001 \mu \mathrm{g} \mathrm{Se} / \mathrm{g} ; 0.001 \mu \mathrm{g} \mathrm{Se} /$ $\mathrm{g} \times 3,500=3.5 \mu \mathrm{g} \mathrm{Se} / \mathrm{g} \mathrm{dw}$, dry weight). It should be noted that the bioaccumulation factor used here is a generalized, conservative value intended to provide a reasonable calculation of projected tissue concentrations. In actual field settings, bioaccumulation factors may range from hundreds to tens-of-thousands, reflecting site-specific conditions of biogeochemistry and selenium cycling. The feed-back provided by monitoring when, and if, the mining permit is issued will reflect these site-specific factors and reveal whether or not the projections were accurate, as well as whether refinements to the selenium loading rate (TMDL) are needed (see Component 5-hazard assessment).

\subsection{Component 4-biological assessment}

It is important to have a complete inventory of the aquatic resources that may be threatened by mine development in order to obtain a comprehensive and ecologically relevant hazard assessment. Make a list of fish and aquatic-related wildlife present in the HU. Characterize fish and wildlife uses of the habitat (feeding, spawning, nesting, migratory stop-overs, etc.), and identify biota of special concern such as endangered or threatened species and management priority species. Document the presence of, and habitat used by, selenium-sensitive species: for example, warm-water fishes such as bass, Micropterus sp., Morone sp., crappie, Pomoxis sp., and sunfish, Lepomis sp.; cold-water fishes such as trout and salmon, Salvelinus sp., Oncorhynchus sp.; waterbirds such as stilts, Himantopus sp., coots, Fulica sp., grebes, Podiceps sp., plovers, Charadrius sp., and ducks, Anas sp. Identify habitats where bioaccumulation would likely be greatest, that is, in locations with high primary productivity and slow-moving or impounded waters (reservoirs, ponds, wetlands, marshes, etc.). The reason for collecting this information is so that any biological issues or concerns can be identified and factored into the TMDL, and environmental monitoring can be focused on the habitats and species of greatest priority and sensitivity to selenium.

\subsection{Component 5-hazard assessment}

At this point the NEPA worker will have gathered all of the information necessary to evaluate the ecological risk posed by the prospective mine. The first step is to determine the hazard level of the projected environmental selenium concentrations. Take the numbers generated from Component 3-Hydrological Assessment and compare them to the following guidelines (Lemly 1993a, 1995):

Projected water concentration $<1 \mu \mathrm{g} \mathrm{Se} / \mathrm{L}=$ no hazard

Projected water concentration 1-2 $\mu \mathrm{g}$ Se/L = minimal hazard

Projected water concentration $2-3 \mu \mathrm{g} \mathrm{Se} / \mathrm{L}=$ low hazard

Projected water concentration 3-5 $\mu \mathrm{g}$ Se/L = moderate hazard

Projected water concentration $>5 \mu \mathrm{g} \mathrm{Se} / \mathrm{L}=$ high hazard

Projected tissue concentration $<3 \mu \mathrm{g}$ Se $/ g$, dw (dry weight) $=$ no hazard

Projected tissue concentration 3-5 $\mu \mathrm{g} \mathrm{Se} / \mathrm{g} \mathrm{dw}=$ minimal hazard 
Projected tissue concentration 5-10 $\mu \mathrm{g} \mathrm{Se} / \mathrm{g} \mathrm{dw}=$ low hazard

Projected tissue concentration 10-20 $\mu \mathrm{g} \mathrm{Se} / \mathrm{g} \mathrm{dw}$ $=$ moderate hazard

Projected tissue concentration $>20 \mu \mathrm{g} \mathrm{Se} / \mathrm{g} \mathrm{dw}=$ high hazard

If the highest hazard level for the HU is determined to be minimal or none, then there is little ecological risk from selenium contamination and the mining permit should be approved if there are no other water quality or environmental concerns evident to the NEPA worker. However, if a hazard level of low, moderate, or high is found, then it is necessary to continue with the procedure and determine the Total Maximum Daily Load (TMDL) of selenium that is permissible. Begin by putting the highest hazard level and the RC rating of the HU into the evaluation matrix in Table 2. The table indicates the appropriate amount of load reduction needed: small, medium, or large. The projected total daily selenium load ( $\mathrm{g} /$ day, from Component 2-mine operation assessment) should be reduced by $10 \%$ if the amount designated is small, $25 \%$ if it is medium, and $50 \%$ if it is large (these percentages were derived from field research at the mines used for case examples in this paper by using data for known conditions of RC, selenium loading, and selenium concentrations in water and tissues, as well as equivalent data from field studies of coal-fired power plant discharges in North Carolina and Texas, see Lemly 2002b). Subtract the indicated amount from the projected load to find the TMDL. This is the number that the mine must meet, at a minimum, in order to proceed with the permit process.

Table 2 Amount of selenium load reduction necessary for a hydrological unit (HU) based on hazard rating ${ }^{\mathrm{a}}$ and retention capacity $(\mathrm{RC})^{\mathrm{b}}$

\begin{tabular}{llll}
\hline & \multicolumn{2}{l}{ Hazard rating } & \\
\cline { 2 - 4 } & Low & Moderate & High \\
\hline RC of HU & & & \\
Low & Small & Medium & Large \\
Medium & Medium & Medium & Large \\
High & Medium & Large & Large \\
\hline
\end{tabular}

\footnotetext{
${ }^{\text {a }}$ Highest hazard rating for the HU.

${ }^{\mathrm{b}}$ Necessary load reductions $=10 \%$ for small, $25 \%$ for medium, $50 \%$ for large.
}

The TMDL embodies a suite of environmental quality parameters that account for selenium cycling, bioaccumulation, and toxic hazard. Meeting the TMDL means that these basic environmental quality goals are also met. However, there may also be other ecological, legal, or policy considerations. At this juncture the information from the biological assessment should be closely examined in consultation with experts on the national forest, in the U.S. Fish and Wildlife Service, in state fish and wildlife agencies, or elsewhere to determine if there are overriding concerns; for example, presence of endangered or threatened species in the HU, issues related to the Clean Water Act or Migratory Bird Treaty Act, etc. If so, it may be prudent to deny the mine permit outright. This is a key point in the procedure. The NEPA worker must assimilate all of the available information and make a determination on whether or not to proceed.

The next step is to review the mine's operating parameters to see if it is feasible to reduce projected selenium discharges and meet the TMDL. There are several options for reducing the exposure and weathering of selenium-laden solid materials, and minimizing the amount of wastewater produced (Lemly 1994). Practices such as backfilling, water recirculation, and in-situ leaching are just a few of the possible ways to lower selenium discharges. From the calculations used in Component 2 (Mine Operation Assessment), it follows that reducing the amount of surface residuals and/or wastewater will translate to a lower projected daily load. Chemical/physical treatment of liquid waste to lower selenium concentrations in the discharge is another step that can be taken. Some flexibility on the part of the mining company may be all that is necessary to meet the TMDL. If it is possible for the mine to change operating conditions sufficiently then the permit can be issued. If not, then the NEPA worker should reject the permit based on the expectation of non-compliance with environmental quality goals.

If it appears that the mine can meet the TMDL and the permit is issued, monitoring of water, fish, and birds should be done once mining begins to verify that selenium levels in aquatic habitats remain at safe levels. Monitoring is needed to make sure that the mine is meeting its discharge limits and also as a check on how well the TMDL fits the ecosystem. Remember, the TMDL was generated from calculations that were based on projected selenium levels, 
not actual concentrations. The TMDL may not be a perfect fit to the HU once site-specific environmental conditions that regulate selenium cycling and biological uptake come into play. It is possible that some adjustment of the TMDL may be necessary because of mine-related and/or environmental-related factors. The following guidelines should be used to evaluate the monitoring data; they are maximum allowable selenium concentrations (Lemly 1993a, 2002b):

Water $=2 \mu \mathrm{g} \mathrm{Se} / \mathrm{L}$, filtered samples $(0.45 \mu \mathrm{m}$ pore size)

Fish tissues: whole body $=4 \mu \mathrm{g}$ Se/g dw (dry weight)

skeletal muscle (skinless fillets) $=8 \mu \mathrm{g} \mathrm{Se} / \mathrm{g} \mathrm{dw}$ liver $=12 \mu \mathrm{g} \mathrm{Se} / \mathrm{g} \mathrm{dw}$

ovary and eggs $=10 \mu \mathrm{g} \mathrm{Se} / \mathrm{g} \mathrm{dw}$

Aquatic bird tissues: liver $=10 \mu \mathrm{g} \mathrm{Se} / \mathrm{g} \mathrm{dw}$ eggs $=7 \mu \mathrm{g} \mathrm{Se} / g \mathrm{dw}$

These guideline values are concentrations that will protect fish and wildlife from toxic effects of selenium on reproduction and overwinter survival, which are the most ecologically important impacts of selenium poisoning (Lemly 1993b, 2002a; Skorupa 1998). Selenium residues should be monitored annually in representative habitats focusing on locations where bioaccumulation is likely to be greatest, that is, where water movement is slow and primary productivity is high. Also, selenium-sensitive species and management priority species should be targeted in the monitoring effort. Special attention should be paid to aquatic habitats that were created in the mining process, for example, ponds or lakes formed by water accumulated in mining pits. These habitats may be very attractive to wildlife and can also contain very high levels of selenium, sufficient to poison mammals, birds and amphibians (Skorupa et al. 2002). Concentrations of selenium should be evaluated using the guidelines above, and assigned a hazard level using the guidelines listed at the beginning of this component (hazard will be for measured concentrations rather than projections). If the mine is meeting the TMDL, selenium concentrations are within acceptable levels, and the maximum hazard found is minimal or none, then the TMDL was appropriate and the mine can continue to operate with annual monitoring and review. If selenium concentrations are elevated or if hazard is low, moderate, or high then the initial
TMDL was too high or the mine's actual operating parameters did not match projections. In either case, immediate action is necessary. First, the new hazard ratings should be applied to Table 2 in order to generate a new load reduction percentage. Second, subtract this percentage from the initial TMDL to set the new TMDL (this iterative approach for determining load limits has been recommended before, in the early 1990s, by the San Francisco Bay Regional Water Quality Control Board; Taylor et al. 1992). Review the mine operating parameters to determine if it is possible to further reduce selenium discharges. If the new TMDL is attainable through operational changes (e.g., reduction/backfilling of surface residuals, wastewater volume reduction, chemical/physical treatment of wastewater, etc.) then they should be implemented along with continued monitoring. If these changes are not feasible, then the permit should be revoked and the mine closed, with the stipulation that the mining company reclaim and vegetate all exposed areas to stabilize them and minimize further leaching of selenium. However, it should be noted that even with typical mine reclamation and revegetation efforts there may still be substantial selenium exposure risks to upland wildlife and livestock (Steele 2003), that would have to be avoided through additional measures such as capping the waste spoils with several feet of clay to reduce water infiltration and prevent selenium uptake by plants, containment and treatment of leachate, etc. Thus, there may be a need for long-term site management and environmental monitoring.

\section{Field Validation}

In order for the procedure to be deemed reliable for use by NEPA workers it must prove to be accurate in predicting selenium hazards. To assess this accuracy, validation tests were conducted using field data from three locations where selenium pollution has occurred, two on Caribou National Forest and one on Beaverhead-Deerlodge National Forest. Each of these pollution episodes was well documented in terms of mine operating parameters, selenium concentrations, and resultant environmental hazard. Therefore, a rigorous evaluation of the performance of the procedure was possible. 


\subsection{Case example $1-$ phosphate mining}

The Dry Valley and Enoch Valley phosphate mines on Caribou National Forest, Idaho, were examined using data from existing reports (Desborough et al. 1999; Hamilton and Buhl 2003a, b, 2004, 2005; Hamilton et al. 2002, 2004; Herring 2004; Montgomery Watson 1998, 1999, 2000, 2001a, b, 2002; Skorupa et al. 2002; Tetra Tech EMI 2002; TRC Environmental 1999). The following key information was obtained:

\begin{tabular}{|c|c|c|}
\hline & Dry Valley Mine & $\begin{array}{l}\text { Enoch Valley } \\
\text { Mine }\end{array}$ \\
\hline $\begin{array}{l}\text { Solid waste } \\
\text { leachate selenium } \\
\text { concentrations: }\end{array}$ & 6-44 $\mu \mathrm{g} \mathrm{Se} / \mathrm{L}$ & $<1-184 \mu \mathrm{g} \mathrm{Se} / \mathrm{L}$ \\
\hline $\begin{array}{l}\text { Area of exposed } \\
\text { solid waste: }\end{array}$ & 520 ha & 750 ha \\
\hline $\begin{array}{l}\text { Liquid waste selenium } \\
\text { concentrations: }\end{array}$ & $150-230 \mu \mathrm{g} \mathrm{Se} / \mathrm{L}$ & 94-355 $\mu \mathrm{g} \mathrm{Se} / \mathrm{L}$ \\
\hline $\begin{array}{l}\text { Volume of liquid } \\
\text { waste: }\end{array}$ & $30,000 \mathrm{~L} /$ day & $100,000 \mathrm{~L} /$ day \\
\hline $\begin{array}{l}\text { Measured ambient } \\
\text { waterborne } \\
\text { selenium: }\end{array}$ & $<1-8 \mu \mathrm{g} \mathrm{Se} / \mathrm{L}$ & $<1-26 \mu \mathrm{g} \mathrm{Se} / \mathrm{L}$ \\
\hline $\begin{array}{l}\text { Measured fish } \\
\text { tissue selenium } \\
\text { concentrations: }\end{array}$ & $7-17 \mu \mathrm{g} \mathrm{Se} / \mathrm{g} \mathrm{dw}$ & $5-10 \mu \mathrm{g} \mathrm{Se} / \mathrm{g} \mathrm{dw}$ \\
\hline $\begin{array}{l}\text { Measured bird } \\
\text { tissue selenium } \\
\text { concentrations: }\end{array}$ & $5-59 \mu \mathrm{g} \mathrm{Se} / \mathrm{g} \mathrm{dw}$ & $4-80 \mu \mathrm{g} \mathrm{Se} / \mathrm{g} \mathrm{dw}$ \\
\hline $\begin{array}{l}\text { Hazard rating } \\
\text { for measured } \\
\text { water selenium: }\end{array}$ & High & High \\
\hline $\begin{array}{l}\text { Hazard rating } \\
\text { for measured } \\
\text { fish tissue selenium: }\end{array}$ & Moderate & Moderate \\
\hline $\begin{array}{l}\text { Hazard rating } \\
\text { for measured } \\
\text { bird tissue selenium: }\end{array}$ & High & High \\
\hline $\begin{array}{l}\text { Retention } \\
\text { capacity of the HU: }\end{array}$ & High & High \\
\hline
\end{tabular}

The following parameters were calculated for the Dry Valley Mine:

Selenium load:

Liquid component $=30,000 \mathrm{~L} /$ day $\times 230 \mu \mathrm{g} \mathrm{Se} / \mathrm{L}$ $=6.9 \mathrm{~g} \mathrm{Se} /$ day
Solid component:

Net moisture: $42 \mathrm{~cm}-21 \mathrm{~cm}=21 \mathrm{~cm}$

Total annual leachate: $21 \mathrm{~cm} \times 520$ ha $=$ $52,000,000 \mathrm{~L} / \mathrm{cm} \times 21 \mathrm{~cm}=1,092,000,000 \mathrm{~L}$

Daily leachate volume: $1,092,000,000 \mathrm{~L} \div 365=$ 2,991,780 L/day

Daily selenium load: $44 \mu \mathrm{g} \mathrm{Se} / \mathrm{L} \times 2,991,780 \mathrm{~L} /$ day

$=131.5 \mathrm{~g} \mathrm{Se} /$ day

Maximum total daily load: $6.9 \mathrm{~g} /$ day $+131.5 \mathrm{~g}$ /day $=138.4 \mathrm{~g} \mathrm{Se} /$ day

Projected ambient waterborne selenium: $4.4 \mu \mathrm{g} \mathrm{Se} / \mathrm{L}$ Projected tissue selenium concentrations: $15.4 \mu \mathrm{g}$ $\mathrm{Se} / \mathrm{g} \mathrm{dw}$

Hazard rating for projected water selenium: Moderate

Hazard rating for projected tissue selenium: Moderate

Selenium load reduction needed

(high RC and moderate hazard): $69.2 \mathrm{~g} \mathrm{Se} /$ day (50\% reduction)

Total Maximum Daily Load (TMDL) for HU $69.2 \mathrm{~g}$ Se/day

\subsubsection{Performance evaluation}

Comparing the concentrations of selenium projected from calculations to those measured in the environment indicates that the procedure yielded accurate predictions (projected values for water and tissue, and the resultant hazard ratings, were within the range of measured values). If this had been an actual pre-mine NEPA assessment, the action indicated by the procedure would be to apply the TMDL and modify the mine operating parameters to reduce the projected daily selenium load by $50 \%$. If this reduction was feasible, the mining permit could be issued. This field test indicates that the procedure performed as intended. It correctly identified and quantified selenium hazard, and revealed the steps needed to reduce this hazard to an acceptable level.

The following parameters were calculated for the Enoch Valley Mine:

Selenium load:

Liquid component $=100,000 \mathrm{~L} /$ day $\times 355 \mu \mathrm{g} \mathrm{Se} / \mathrm{L}=$ $35.5 \mathrm{~g} \mathrm{Se} /$ day

Solid component:

Net moisture: $42 \mathrm{~cm}-21 \mathrm{~cm}=21 \mathrm{~cm}$ 
Total annual leachate: $21 \mathrm{~cm} \times 750$ ha $=$ $75,000,000 \mathrm{~L} / \mathrm{cm} \times 21 \mathrm{~cm}=1,575,000,000 \mathrm{~L}$

Daily leachate volume: $1,575,000,000 \mathrm{~L} \div 365=$ 4,315,068 L/day

Daily Selenium load: $184 \mu \mathrm{g} \mathrm{Se} / \mathrm{L} \times 4,315,068 \mathrm{~L} /$ day $=794 \mathrm{~g} \mathrm{Se} /$ day

Maximum total daily load: $35.5 \mathrm{~g} / \mathrm{day}+794 \mathrm{~g} /$ day $=829.5 \mathrm{~g} \mathrm{Se} /$ day

Projected ambient waterborne selenium: $18.4 \mu \mathrm{g}$ $\mathrm{Se} / \mathrm{L}$

Projected tissue selenium concentrations: $64.4 \mu \mathrm{g}$ $\mathrm{Se} / \mathrm{g}$ dw

Hazard rating for projected water selenium: High

Hazard rating for projected tissue selenium: High

Selenium load reduction needed

(high RC and high hazard): $414.8 \mathrm{~g}$ Se/day (50\% reduction)

Total Maximum Daily Load (TMDL) for HU 414.8 g Se/day

\subsubsection{Performance evaluation}

Comparing the concentrations of selenium projected from calculations to those measured in the environment indicates that the procedure yielded accurate predictions (projected values for water and tissue, and the resultant hazard ratings, were within the range of measured values). If this had been an actual pre-mine NEPA assessment, the action indicated by the procedure would be to apply the TMDL and modify the mine operating parameters to reduce the projected daily selenium load by $50 \%$. If this reduction was feasible, the mining permit could be issued. This field test indicates that the procedure performed as intended. It correctly identified and quantified selenium hazard, and revealed the steps needed to reduce this hazard to an acceptable level.

\subsection{Case example 2-gold mining}

The Beal Mountain Gold Mine on Beaverhead-Deerlodge National Forest, Montana, was examined using data from existing reports (Farmer and Weber 1995; La Marr 2002, 2003; USDA-FS 1988), personal communications (Timothy La Marr, Fisheries Biologist, Beaverhead-Deerlodge National Forest, Butte, MT; Bruce Parker, Mine Manager, Beal Mountain Gold Mine, Butte, MT), and new information from selenium leaching tests conducted specifically for this study. The following key information was obtained:

\begin{tabular}{ll}
\hline & Beal Mountain Mine \\
\hline $\begin{array}{l}\text { Solid waste leachate selenium } \\
\text { concentrations: }\end{array}$ & $129-668 \mu \mathrm{g} \mathrm{Se} / \mathrm{L}$ \\
Area of exposed solid waste: & $165 \mathrm{ha}$ \\
Liquid waste selenium concentrations: & $210-491 \mu \mathrm{g} \mathrm{Se} / \mathrm{L}$ \\
Volume of liquid waste: & $170,000 \mathrm{~L} / \mathrm{day}$ \\
Measured ambient waterborne selenium: & $<1-19 \mu \mathrm{g} \mathrm{Se} / \mathrm{L}$ \\
Measured fish tissue selenium & $10-50 \mu \mathrm{g} \mathrm{Se} / \mathrm{g} \mathrm{dw}$ \\
concentrations: & High \\
Hazard rating for measured water & \\
selenium: & High \\
Hazard rating for measured tissue & \\
selenium: & Low \\
Retention capacity of the HU: & \\
\hline
\end{tabular}

The following parameters were calculated for the Beal Mountain Mine:

Selenium load:

Liquid component $=170,000 \mathrm{~L} /$ day $\times 491 \mu \mathrm{g} \mathrm{Se} / \mathrm{L}=$ $83.5 \mathrm{~g} \mathrm{Se} /$ day

Solid component:

Net moisture: $34 \mathrm{~cm}-17 \mathrm{~cm}=17 \mathrm{~cm}$

Total annual leachate: $17 \mathrm{~cm} \times 165 \mathrm{ha}=$ $16,500,000 \mathrm{~L} / \mathrm{cm} \times 17 \mathrm{~cm}=280,500,000 \mathrm{~L}$

Daily leachate volume: $280,500,000 \mathrm{~L} \div 365=$ 768,493 L/day

Daily Selenium load: $668 \mu \mathrm{g} \mathrm{Se} / \mathrm{L} \times 768,493 \mathrm{~L} /$ day $=513 \mathrm{~g} \mathrm{Se} /$ day

Maximum total daily load: $83.5 \mathrm{~g} /$ day $+513 \mathrm{~g} /$ day $=596.5 \mathrm{~g} \mathrm{Se} /$ day

Projected ambient waterborne selenium: $6.7 \mu \mathrm{g}$ Se/L Projected tissue selenium concentrations: $23.5 \mu \mathrm{g}$ $\mathrm{Se} / \mathrm{g}$ dw

Hazard rating for projected water selenium: High Hazard rating for projected tissue selenium: High Selenium load reduction needed

(low RC and high hazard): $298.3 \mathrm{~g} \mathrm{Se} /$ day $(50 \%$ reduction)

Total Maximum Daily Load (TMDL) for HU 298.3 g Se/day

\subsubsection{Performance evaluation}

Comparing the concentrations of selenium projected from calculations to those measured in the environ- 
ment indicates that the procedure yielded accurate predictions (projected values for water and tissue, and the resultant hazard ratings, were within the range of measured values). If this had been an actual pre-mine NEPA assessment, the action indicated by the procedure would be to apply the TMDL and modify the mine operating parameters to reduce the projected daily selenium load by $50 \%$. If this reduction was feasible, the mining permit could be issued. This field test indicates that the procedure performed as intended. It correctly identified and quantified selenium hazard, and revealed the steps needed to reduce this hazard to an acceptable level.

\section{Conclusions}

NEPA responsibilities in the Forest Service are carried out by a variety of workers with backgrounds well suited for activities such as forest and aquatic habitat management but without the professional training and experience necessary for contaminant risk assessment. Selenium pollution may seem to be a formidable topic that is better left for others to deal with. However, NEPA requires that all potential environmental damage emanating from land disturbance be assessed, which carries an inherent expectation that there is an awareness of, and responsiveness to, contaminant issues for water, land, and air. Mining, in particular, involves selenium hazards that must be recognized and addressed. By utilizing the procedure laid out in this paper, NEPA workers can be confident in their ability to understand the risk of aquatic selenium pollution and take appropriate action. The procedure makes environmentally sound NEPA assessment possible and, thereby, affords protection to aquatic resources on national forests. Furthermore, it provides two key pieces of information for the Forest Service and NEPA workers in the event that legal challenges arise: 1) documentation that a scientifically credible procedure was used to reach decisions on mining permit applications, and 2) documentation that sound physical, chemical, and biological data were gathered and used in the process. These two pieces of information were missing in the pollution examples given at the beginning of this paper. If they had been available for use by the Forest Service in the mine permitting process, the pollution episodes, as well as the lawsuits associated with them, could have been avoided.
Although the procedure was developed for the Forest Service, other federal land management agencies that conduct NEPA assessments should also find it useful; for example, the Fish and Wildlife Service, Bureau of Land Management, and Bureau of Reclamation. It should also be useful to regulatory agencies responsible for issuing coal mining permits under the authority of the Surface Mining Control and Reclamation Act (SMCRA), and associated Section 401 water quality certification under the Clean Water Act. Mining companies will also benefit from the application of this procedure because priority selenium sources can be identified in relation to specific mine operating parameters. The procedure will reveal the point(s) at which there is a need to modify operating conditions to meet environmental quality goals. By recognizing concerns early in the NEPA process, it may be possible for a mining company to match operational parameters with environmental requirements, thereby increasing the likelihood that the permit application will be approved.

Acknowledgements The author thanks Timothy La Marr and Bruce Parker for providing information on operating conditions and collecting samples of solid waste from the Beal Mountain Gold Mine, Montana. Thanks also to the U.S. Geological Survey for providing data from selenium leaching tests for the Dry Valley and Enoch Valley phosphate mines in southeast Idaho and the Beal Mountain Gold Mine.

\section{References}

ASTM (American Society for Testing and Materials). (2004). Standard test method for shake extraction of solid waste with water. Method D3987-85. West Conshohocken, PA: ASTM International.

CCS (Caribou County Sun). (1999). Toxicologist and vet say dead sheep likely died from selenium. Newspaper Article, November 11, Soda Springs, Idaho.

Davis, E. C., \& Boegly, W. J. Jr. (1981). Coal pile leachate quality. J. Environ. Eng. Div. Proc. Amer. Soc. Civil Eng., 107, 399-417.

Desborough, G., DeWitt, E., Jones, J., Meier, A., \& Meeker, G. (1999). Preliminary mineralogical and chemical studies related to the potential mobility of selenium and associated elements in phosphoria formation strata, Southeastern Idaho (pp. 99-129). Open File Report. Denver, Colorado: U.S. Geological Survey.

Farmer, C., \& Weber, E. (1995). Beal mountain project, aquatic biological monitoring: 1993-1994. Technical Report. Anaconda, Montana: Beal Mountain Mining, Inc.

GYC (Greater Yellowstone Coalition). (1999). GYC appeals mine expansion citing public health and water quality concerns. News Release, September 22. Bozeman, Montana: Greater Yellowstone Coalition. 
Hamilton, S. J., \& Buhl, K. J. (2003a). Selenium and other trace elements in water, sediment, aquatic plants, aquatic invertebrates, and fish from streams in Southeastern Idaho near phosphate mining operations: September 2000. Technical Report. Yankton, South Dakota: U.S. Geological Survey, Field Research Station.

Hamilton, S. J., \& Buhl, K. J. (2003b). Selenium and other trace elements in water, sediment, aquatic plants, aquatic invertebrates, and fish from streams in Southeastern Idaho near phosphate mining operations: May 2001. Technical Report. Yankton, South Dakota: U.S. Geological Survey, Field Research Station.

Hamilton, S. J., \& Buhl, K. J. (2004). Selenium in water, sediment, plants, invertebrates, and fish in the Blackfoot River drainage. Water, Air and Soil Pollution, 159, 3-34.

Hamilton, S. J., \& Buhl, K. J. (2005). Selenium in the Blackfoot, Salt, and Bear river watersheds. Environmental Monitoring and Assessment, 104, 309-339.

Hamilton, S. J., Buhl, K. J., \& Lamothe, P. J. (2002). Selenium and other trace elements in water, sediment, aquatic plants, aquatic invertebrates, and fish from streams in Southeastern Idaho near phosphate mining operations: June 2000. Technical Report. Yankton, South Dakota: U.S. Geological Survey, Field Research Station.

Hamilton, S. J., Buhl, K. J., \& Lamothe, P. J. (2004). Selenium and other trace elements in water, sediment, aquatic plants, aquatic invertebrates, and fish from streams in SE Idaho near phosphate mining. In J. R. Hein (Ed.), Life cycle of the phosphoria formation: From deposition to the postmining environment, Handbook of exploration and environmental geochemistry, Volume 8 (pp. 483-525). New York: Elsevier.

Heaton, R. C., \& Wagner, P. (1983). Trace element characterization of coal preparation wastes. Technical Report. LA9626. Los Alamos, New Mexico: Los Alamos National Laboratory.

Heaton, R. C., Williams, J. M., Bertino, J. P., Wangen, L. E., Nyitray, A. M., Jones, M. M., et al. (1982). Leaching behaviors of high-sulfur coal wastes from two Appalachian coal preparation plants. Technical Report. LA9356-MS. Los Alamos, New Mexico: Los Alamos National Laboratory.

Herring, J. R. (2004). Rock leachate geochemistry of the Meade peak phosphatic shale member of the phosphoria formation, Southeast Idaho. In J. R. Hein (Ed.), Life cycle of the phosphoria formation: From deposition to the post-mining environment, Handbook of exploration and environmental geochemistry, Volume 8 (pp. 367-398). New York: Elsevier.

IFPR (Idaho Falls Post Register) (2003). Coalition aims suit at Poison mine waste. Newspaper Article, September 11. Idaho Falls, Idaho: Idaho Falls Post Register.

La Marr, T. J. (2002). Selenium and copper concentrations in fish and aquatic macroinvertebrate tissues in the German Gulch subwatershed, prior to land application of treated mine solution, Summer 2001. Technical Report. U.S. Forest Service, Beaverhead-Deerlodge National Forest, Butte and Jefferson Ranger Districts, Butte, Montana.

La Marr, T. J. (2003). Aquatic hazard assessment for selenium in the German Gulch subwatershed, Beaverhead-Deerlodge national forest, Montana, based on 2001 and 2002
Data, Technical Report. U.S. Forest Service, BeaverheadDeerlodge National Forest, Butte and Jefferson Ranger Districts, Butte, Montana.

Lemly, A. D. (1985). Toxicology of selenium in a freshwater reservoir: Implications for environmental hazard evaluation and safety. Ecotoxicology and Environmental Safety, 10, 314-338.

Lemly, A. D. (1993a). Guidelines for evaluating selenium data from aquatic monitoring and assessment studies. Environmental Monitoring and Assessment, 28, 83-100.

Lemly, A. D. (1993b). Metabolic stress during winter increases the toxicity of selenium to fish. Aquatic Toxicology, 27, $133-158$.

Lemly, A. D. (1994). Mining in northern Canada: Expanding the industry while protecting Arctic fishes. Ecotoxicology and Environmental Safety, 29, 229-242.

Lemly, A. D. (1995). A protocol for aquatic hazard assessment of selenium. Ecotoxicology and Environmental Safety, 32, 280-288.

Lemly, A. D. (1996). Ecosystem recovery following selenium contamination in a freshwater reservoir. Ecotoxicology and Environmental Safety, 36, 275-281.

Lemly, A. D. (1998). A position paper on selenium in ecotoxicology: A procedure for deriving site-specific water quality criteria. Ecotoxicology and Environmental Safety, 39, 1-9.

Lemly, A. D. (1999). Preliminary assessment of selenium hazards on Caribou National Forest, Idaho. Technical Report. U.S. Forest Service, Southern Research Station, Coldwater Fisheries Research Unit, Blacksburg, Virginia.

Lemly, A. D. (2002a). Symptoms and implications of selenium toxicity in fish: The Belews Lake case example. Aquatic Toxicology, 57, 39-49.

Lemly, A. D. (2002b). A procedure for setting environmentally safe total maximum daily loads (TMDLs) for selenium. Ecotoxicology and Environmental Safety, 52, 123-127.

Lemly, A. D. (2004). Aquatic selenium pollution is a global environmental safety issue. Ecotoxicology and Environmental Safety, 59, 44-56.

Lemly, A. D., \& Smith, G. J. (1987). Aquatic cycling of selenium: Implications for fish and wildlife, fish and wildlife leaflet 12. Washington, District of Columbia: U.S. Fish and Wildlife Service

Montgomery Watson. (1998). Fall 1997 Interim surface water survey report, Southeast Idaho phosphate resource area selenium project. Technical Report. Steamboat Springs, Colorado: Montgomery Watson Mining Group.

Montgomery Watson. (1999). Final 1998 regional investigation report, Southeast Idaho phosphate resource area selenium project. Technical Report. Steamboat Springs, Colorado: Montgomery Watson Mining Group.

Montgomery Watson. (2000). 1999 Interim investigation data report, Southeast Idaho phosphate resource area selenium project. Technical Report. Steamboat Springs, Colorado: Montgomery Watson Mining Group.

Montgomery Watson. (2001a). Draft 1999-2000 regional investigation data report for surface water, sediment, and aquatic biota sampling activities, September 1999, Southeast Idaho phosphate resource area selenium project. Technical Report. Steamboat Springs, Colorado: Montgomery Watson Mining Group. 
Montgomery Watson. (2001b). Draft 1999-2000 regional investigation data report for surface water, sediment, and aquatic biota sampling activities, May-June 2000, Southeast Idaho phosphate resource area selenium project. Technical Report. Steamboat Springs, Colorado: Montgomery Watson Mining Group.

Montgomery Watson. (Montgomery Watson Harza) (2002). Spring 2001 area-wide investigation data transmittal. Technical Report. Bellevue, Washington: Montgomery Watson Harza.

Ogle, R. S., Maier, K. J., Kiffney, P., Williams, M. J., Brasher, A., Melton, L. A., et al. (1988). Bioaccumulation of selenium in aquatic ecosystems. Lake and Reservoir Management, 4, 165-173.

Ohlendorf, H. M. (1989). Bioaccumulation and effects of selenium in wildlife. In Selenium in Agriculture and the Environment, Special Publication 23 (pp. 133-177). Madison, Wisconsin: Soil Science Society of America.

Ohlendorf, H. M., Kilness, A. W., Simmons, J. L., Stroud, R. K., Hoffman, D. J., \& Moore, J. F. (1988). Selenium toxicosis in wild aquatic birds. Journal of Toxicology and Environmental Health, 24, 67-92.

Perkins, R. B., \& Foster, A. L. (2004). Mineral affinities and distribution of selenium and other trace elements in black shale and phosphorite of the phosphoria formation. In J. R. Hein (Ed.), Life cycle of the phosphoria formation: From deposition to the post-mining environment, Handbook of exploration and environmental geochemistry, Volume 8 (pp. 251-298). New York: Elsevier.

Piper, D. Z., Skorupa, J. P., Presser, T. S., Hardy, M. A., Hamilton, S. J., Huebner, M., et al. (2000). The phosphoria formation at the hot springs mine in Southeast Idaho: A source of selenium and other trace elements to surface water, ground water, vegetation, and biota. Open File Report, 00-050, Menlo Park, California: U.S. Geological Survey.
Skorupa, J. P. (1998). Selenium poisoning of fish and wildlife in nature: Lessons from twelve real-world examples. In W. T. Frankenberger \& R. A. Engberg (Eds.), Environmental chemistry of selenium (pp. 315-354). New York, NY: Marcel Dekker.

Skorupa, J. P., Detwiler, S., \& Brassfield, R. (2002). Reconnaissance survey of selenium in water and avian eggs at selected sites within the phosphate mining region near Soda Springs, Idaho, May-June, 1999. Technical Report. U.S. Fish and Wildlife Service, Division of Environmental Contaminants, Investigations Branch, Sacramento, California.

Steele, M. (2003). Vegetation high in selenium kills 327 sheep at study site. Newspaper Article, June 19. Soda Springs, Idaho: Caribou County Sun.

Taylor, K., Pease, W., Lacy, J., \& Carlin, M. (1992). Mass emissions reduction strategy for selenium. Technical Report. Oakland, California: San Francisco Bay Regional Water Quality Control Board.

Tetra Tech EMI. (2002). Final area wide human health and ecological risk assessment, selenium project, Southeast Idaho phosphate mining resource area, December 2002. Technical Report. Denver, Colorado: Tetra Tech Environmental Monitoring, Inc.

TRC Environmental. (1999). Maybe canyon site investigation, Caribou National Forest, Caribou County, Idaho. Technical Report. Englewood, Colorado: TRC Environmental Corporation.

USDA-FS (United States Department of Agriculture-Forest Service). (1988). Environmental assessment and preliminary environmental review, Beal Mountain Project, Environmental Assessment, Butte Ranger District, Beaverhead-Deerlodge National Forest, Butte, Montana.

USDC (United States District Court). (2002). Clark Fork Coalition vs. Thomas Reilly, Lawsuit, December 10, U.S. District Court for the District of Montana, Missoula Division, Missoula County, Montana. 